\title{
CONFUNDINDO PARA ESCLARECER: ALGUNS PROCEDIMENTOS BRECHTIANOS EM TOM ZÉ
}

\author{
CONFUSING TO CLARIFY: A FEW BRECHTIAN PROCEDURES IN TOM ZÉ
}

Leilor Miranda Soares ${ }^{1}$

\begin{abstract}
Resumo: Este artigo observa a presença de um efeito de distanciamento no disco Estudando o samba (1976), de Tom Zé, pela análise de das canções "Tô" e "Ui (você inventa)". Esse efeito, que identificaremos através de paralelos com a obra de Bertolt Brecht, colabora para a construção de um ponto de vista de outsider, o qual formaliza a posição marginal ocupada por Tom Zé no mercado fonográfico à época.

Abstract: This article observes the presence of a distancing effect in the álbum Estudando o samba (1976), by Tom Zé, through the analysis of the songs "Tô" and "Ui (você inventa)". This effect, which we will identify by making parallels with Bertolt Brecht's work, helps the construction of na outsider point of view that formalizes the marginal position in the phonographic market occupied by Tom Zé at the time.
\end{abstract}

Palavras-chave: Tom Zé; MPB; Bertolt Brecht; Indústria fonográfica.

Keywords: Tom Zé; MPB; Bertolt Brecht; Fonografic industry.

Lançado em meio ao chamado "ostracismo" vivido por Tom Zé ao longo da década de 1970, o álbum Estudando o samba (1976) desdobra a guinada em direção ao experimentalismo iniciada no antecessor Todos os olhos (1973). Mais do que isso, o movimento iniciado no disco de 1973 e aprofundado em Estudando o samba é o de construir um ponto de vista de outsider em relação à $\mathrm{MPB}^{2}$, que formaliza a posição marginal ocupada por Tom Zé no mercado e a partir do qual o compositor observa e comenta criticamente a MPB e o próprio mercado, como quem os vê "de fora". Parte da construção desse ponto de vista se dá através do experimentalismo musical, que busca se distanciar das formas consolidadas da canção popular ${ }^{3}$. A parte de que trataremos aqui diz respeito à presença de um efeito de distanciamento em Estudando o samba, alcançado por alguns procedimentos que chamaremos de brechtianos, os quais complementam e se articulam com os momentos de maior experimentalismo do disco.

1 Mestre pelo Instituto de Estudos Brasileiros da Universidade de São Paulo (IEB-USP).

2 Por MPB, entende-se aqui uma certa fração da canção popular brasileira, que se formou a partir de um deslocamento do lugar social da canção no Brasil iniciado com a bossa nova e cristalizado ao longo dos ano $1960 \mathrm{com}$ a canção engajada e o tropicalismo. Alguns dos expoentes dessa fração, que se institucionalizou como setor dinâmico da indústria fonográfica na década de 1970, são Chico Buarque, Caetano Veloso, Gilberto Gil e Milton Nascimento. Ver Marcos Napolitano $(2002,2010)$ e Marcia Tosta Dias (2008).

3 Sobre os procedimentos especificamente musicais do projeto estético de Tom Zé, ver Leonardo Bomfim (2014), Guilherme Freire (2015) e Leilor Soares (2019). 
Não se pretende afirmar que houve uma influência direta e consciente da obra de Bertolt Brecht em Estudando o samba, mas explorar algumas similaridades entre certas técnicas de distanciamento do teatro épico e procedimentos utilizados por Tom Zé. Salvo engano, a primeira a sugerir tal aproximação foi Patrícia Gonçalves (2018), ao analisar a construção literária do relato autobiográfico do compositor iraraense, intitulado Tropicalista lenta luta (2003), no qual a autora nota a busca por um leitor "atento, participante, crítico" (2018, p. 67). Um dos elementos formais do texto que apoiam a percepção da autora é a presença de uma série de rubricas teatrais que interrompem com frequência a narrativa autobiográfica. Na primeira parte do relato, as rubricas "falam de um público que, à medida que lê o livro, deglute pedaços do narrador-personagem" e a suspensão que elas promovem abre espaço para uma "reflexão estética e teatral interna ao relato" (2018, p. 67). Também nessa parte, há um trecho que se intitula "brincadeira-brecht". Ao notar essa menção aBrecht feita por Tom Zé, Gonçalves afirma que o compositor intui um parentesco em sua fórmula cancional-teatral com a técnica do distanciamento brechtiano, que também se faz presente no relato autobiográfico:

Por essa 'brincadeira-brecht' o narrador se aproxima ainda uma vez de seu leitor-ouvinte, criando para ele uma situação de distância narrativa, colocando sua narração a serviço de sua própria crítica, quando estabelece a falsidade do improviso de suas quadrinhas e, no limite de sua própria narração (2018, p. $70)$.

Em Brecht, o efeito de distanciamento, também chamado de estranhamento ou desnaturalização, busca, ao introduzir a distância narrativa na peça por meio de uma série de técnicas, em oposição à identificação dramática, manter o público lúcido diante do espetáculo, com uma atitude crítica em face aos acontecimentos. Em que pesem as consideráveis diferenças entre Brecht, Tom Zé e seus respectivos projetos, a começar pelos países, contextos históricos e pelo fato de que um fazia teatro e o outro faz música popular, chamam a atenção algumas afinidades eletivas. Parece ser essa mesma atitude crítica a buscada por Tom Zé em seu público, como vimos acima, tanto em sua canção, como em seu próprio relato autobiográfico e em ambos o compositor se utiliza também de técnicas e recursos para tal, que por sua vez também produzem efeitos de distanciamento. No disco Estudando o samba, o distanciamento advém: do caráter de estudo do álbum, que faz com que, antes de ser um disco de samba, ele seja um disco sobre samba e também sobre bossa nova, MPB e tropicalismo, em que as canções comentam a si mesmas;da distância irônica tomada em relação ao padrão de "belo" representado pela MPB musical e poeticamente e da articulação, relacionada a todos esses elementos e que já apontamos acima, de um ponto de vista exterior à MPB, o qual formaliza a posição de Tom Zé na estrutura do mercado.

Nas canções que aqui analisaremos, o distanciamento também se relaciona com a maneira como 
Tom Zé as canta.Voltando para seu relato autobiográfico, Tom Zé procura mostrar, através de anedotas sobre suas tentativas fracassadas de cantar, tocar violão e produzir canções, que a deficiência está na origem de sua atividade artística desde a juventude. A alegada incapacidade do iraraense de produzir uma canção que estivesse de acordo com os padrões da época o levou a buscar uma "descanção" ou "anticanção", o que envolvia "renunciar à beleza - beleza ligada a tudo que era do canto e do cantar" (2003, p. 17). Ao analisar esse ato de cantar e essa beleza dos quais ele busca se distanciar, Tom Zé contrapõe-se essencialmente a duas coisas: uma determinada maneira "expressionista" de cantar, que o iraraense é capaz de identificar com precisão e descrever com termos técnicos, mas não é (ou diz não ser) capaz de reproduzir e o "amor" como assunto por excelência das canções. Além disso, o compositor busca também se desvencilhar do efeito causado pela combinação desses dois elementos, que ele chama de "transe dramático" (2003, p. 20). Para construir sua "descanção" que renunciasse a todos esses elementos, Tom Zé afirma que precisou, entre outras coisas, encontrar um novo "acordo tácito". Tal ideia parte da percepção de que havia algumas regras implícitas na relação entre cantor e espectador/ouvinte que protegiam o primeiro e davam apoio a seu modo de cantar, visto como uma encenação. Desse modo, para colocar em prática sua maneira própria de cantar e fazer canções, $o$ primeiro passo seria trocar as regras dessa relação, "substituindo a empatia gerada pela emoção" e rompendo "o elo forjado pela dramatização expressionista" (2003, p. 22).

Antes de entrarmos na análise de "Tô", cabem alguns comentários acerca de seu papel no interior de Estudando o samba, o qual é pensado aqui como um álbum, no sentido forte da palavra, como um todo coerente e orgânico, cujas canções individuais possuem uma certa autonomia, mas que, ao se juntarem passam a compor uma narrativa ou mensagem maior. "Tô" se constitui na quarta faixa do LP, o que é de especial interesse, já que as três faixas anteriores são justamente as mais experimentais de todo o disco do ponto de vista musical e formam uma espécie de tríade programática do ponto de vista estético-musical de Estudando o samba, ou a "tese" do disco, como afirma Christopher Dunn (2018). Assim, a primeira faixa "Mã" tem sua estrutura dada pela sobreposição tensa e repetitiva de ostinatos, recusando a movimentação harmônica e apresentando o nascimento de um neném, que pode ser entendido ao mesmo tempo como o nascimento do samba e do próprio disco, com seu projeto estético próprio. A segunda faixa se constitui numa versão de "A felicidade", bossa nova conhecida de Tom Jobim e Vinicius de Moraes, com a fórmula de compasso alterada, sobrepondo paradigmas rítmicos binários e ternários. Já a terceira, "Toc", parte de um paradigma rítmico característico do samba carioca para ir desarticulando-o pela introdução de elementos aleatórios tanto rítmica quanto timbristicamente, com sons de enceradeira, máquina de escrever, liquidificador, buzina, gravações de gritos, grunhidos, pessoas falando e transmissões de rádio.Se o disco começa nos primórdios do samba, retratados em "Mã" pelo coro de lavadeiras, passa pela bossa nova, tida como grande salto modernizador não só no samba como na canção popular brasileira em geral, em "Toc" temos a 4 Ver, sobre isso, as reflexões de Márcia Tosta Dias (2012) e Lorenzo Mammí (2014).

Revista Crioula - $\mathbf{n}^{\circ} \mathbf{2 6}$ - Relações entre literatura e música na produção de língua portuguesa

$2^{\circ}$ Semestre 2020 
desagregação quase completa tanto do samba como da própria forma da canção popular. É como se o disco traçasse uma linha que vai do nascimento do samba nas tradições orais da Bahia, passa pela bossa nova e chega a uma desagregação extrema da canção, sempre com a reposição das tensões entre arcaico e moderno, o que parece revelar um esforço no sentido de desarticular tanto a forma perfeita da bossa nova como a forma agressiva do tropicalismo, talvez as duas bases daquilo que veio a se constituir na MPB.

"Tô"”

Após esta trinca que apresenta musicalmente a proposta estética de Tom Zé, a quarta faixa, “Tô", apresenta a "explicação" verbal dessa proposta. É relevante o fato de que se trata de uma canção bastante convencional do ponto de vista musical, de forma ABAB e com estruturas harmônicas, melódicas e rítmicas comuns ao samba. Justamente o fato de se tratar de uma canção convencional faz com que "Tô" se destaque e apareça, de certa forma, como uma surpresa depois das três primeiras faixas. Mais do que uma surpresa, "Tô" é uma interrupção. As três faixas anteriores trabalham com a sobreposição de estruturas ou imagens antagônicas a partir de um ponto de vista que parece se colocar como exterior, ficando difícil de especificar onde ele se situa. Um dos principais elementos para produzir esse efeito é o fato de Tom Zé, de certa forma, não aparecer nas três faixas: em duas ele não canta ("Mã" e "Toc") e na outra ele canta palavras que não são dele e que entram na obra como uma imagem que é relativizada pelo procedimento empregado ("A felicidade"). Diante disso, "Tô" se constitui no momento em que Tom Zé interrompe a sequência de experimentos, justamente após o mais radical deles, e diz algo pela primeira vez como Tom Zé.

Entrando no conteúdo daquilo que Tom Zé diz nessa primeira aparição, fica claro que ele está falando sobre os próprios procedimentos utilizados nas faixas anteriores e que "Tô" figura como uma espécie de manifesto de Estudando o samba. Depois de mostrar a estética proposta, o compositor para a demonstração para explicá-la ao público. A letra, como já foi notado em diversas ocasiões, explora uma série de ideias antagônicas, ou seja, faz verbalmente o que as anteriores fizeram musicalmente. Observemos mais de perto como se dá essa exploração de ideias antagônicas na letra:

\author{
Tô bem de baixo pra poder subir \\ Tô bem de cima pra poder cair \\ Tô dividindo pra poder sobrar \\ Desperdiçando pra poder faltar \\ Devagarinho pra poder caber \\ Bem de leve pra não perdoar
}

Revista Crioula - $\mathbf{n}^{\circ} \mathbf{2 6}$ - Relações entre literatura e música na produção de língua portuguesa

$2^{\circ}$ Semestre 2020 
Tô estudando pra saber ignorar

Eu tô aqui comendo para vomitar

Eu tô te explicando

Pra te confundir

Tô te confundindo

Pra te esclarecer

Tô iluminado

Pra poder cegar

Tô ficando cego

Pra poder guiar

Suavemente pra poder rasgar

Olho fechado pra te ver melhor

Com alegria pra poder chorar

Desesperado pra ter paciência

Carinhoso pra poder ferir

Lentamente pra não atrasar

Atrás da vida pra poder morrer

Eu tô me despedindo pra poder voltar

É comum ler sobre esta letra que ela trabalha com paradoxos. Preferimos dizer que ela explora ideias antagônicas e as organiza às vezes de maneira paradoxal e às vezes não. É precisamente essa organização que nos interessa aqui. Assim, olhando para a primeira estrofe, vemos que não há nenhum paradoxo: as ideias antagônicas como baixo/cima, sobrar/faltar, estudar/ignorar não se chocam a ponto de produzirem estruturas ilógicas ou sem sentido. Ao contrário, é necessário estar de baixo para poder subir e estar de cima para descer. Nesses dois primeiros versos, o sentido ainda é reforçado pela melodia, que sobe do grave para o agudo no primeiro e desce do agudo para o grave no segundo. Essa forte adequação de sentido entre melodia e letra nos dois primeiros versos é digna de nota e traz duas implicações imediatas para a canção: em primeiro lugar, ela reforça o caráter de interrupção por contraste em relação às faixas anteriores. Logo após o álbum atingir seu ápice de experimentalismo em "Toc", com sua estrutura caótica e imprevisível, tem-se o final abrupto da terceira faixa, como se ela fosse efetivamente interrompida por "Tô", que contrasta com "Toc" de todas as maneiras possíveis, não só pela estética convencional, mas por apresentar, como vimos, a primeira aparição de Tom Zé, que surge dizendo não dois paradoxos, mas duas obviedades reforçadas didaticamente pela 
melodia, como se introduzisse no disco um choque de normalidade. Em segundo lugar, essa relação entre letra e melodia nos dois versos iniciais introduz a metalinguagem como, talvez, a principal camada de sentido da canção, como se a letra falasse da melodia e vice-versa, colocando a canção como tema de si mesma.

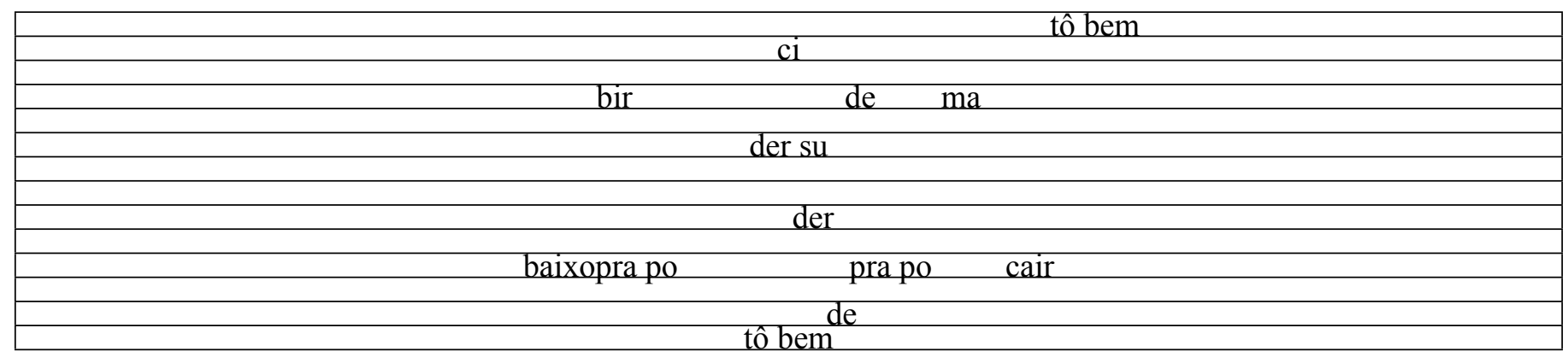

Ex. 01: Diagrama das alturas dos dois primeiros versos de "Tô", inspirado no modelo semiótico desenvolvido por Luiz Tatit. Cada linha representa um semitom da escala cromática.

Após a normalidade desses dois primeiros versos, o movimento geral da letra de "Tô" é o de ir reintroduzindo a anormalidade aos poucos. Assim, por exemplo, a ideia de desperdiçar para poder faltar não traz algo de paradoxal, mas, talvez, de irracional, avesso ao bom senso, ao passo que não há absolutamente nada de errado com “devagarinho pra poder caber". Os dois últimos versos da primeira estrofe voltam a se referir de maneira mais direta ao próprio disco e aparecem como uma espécie de antecipação do refrão, que sintetiza o propósito didático-explicativo e autorreferencial de "Tô". Mais do que isso, o refrão completa o gesto inicial de Estudando o samba, que é o de construir nas três primeiras faixas uma atmosfera que, a partir da incorporação experimental de elementos do samba, da bossa nova e do tropicalismo, relativiza todas as bases da MPB, consolidada como setor dinâmico do mercado fonográfico, naturalizando a transgressão dos padrões estabelecidos por ela. Se nas três faixas iniciais, a transgressão é a norma, a quarta começa com a transgressão da transgressão. Olhando por esse ângulo, a lógica perfeita dos dois primeiros versos de "Tô" passa a ter algo de paradoxal, pois salta aos olhos (ou aos ouvidos) não pela estranheza, mas pela normalidade. Ao analisar a utilização de alguns recursos de distanciamento na obra de Brecht, como a ironia e o grotesco, Anatol Rosenfeld (2008) diz que Brecht se distancia de outras correntes que também utilizam o grotesco, como Kafka e o Teatro de Vanguarda, pois, enquanto estes exprimem "através do grotesco a desorientação em face de uma realidade tornada estranha e imperscrutável", Brecht "usa recursos grotescos e torna o mundo desfamiliar a fim de explicar e orientar" (p. 158, grifo nosso). A ideia que orienta o disco Estudando $o$ samba e que está resumida no refrão de "Tô" é muito próxima: tornar familiar o desfamiliar e viceversa, mas sempre com intenção didática. É nesse sentido que vale a pena destacar mais uma vez o fato de que a normalidade inicial de "Tô" interrompe justamente o momento mais caótico do disco. 
Em vez de aprofundar-se completamente em uma desarticulação experimental que poderia levar à incompreensão, o processo é interrompido e comentado. O comentário, por sua vez, ao mesmo tempo em que interrompe a lógica musical que estava em curso, verbaliza-a e traz na estrutura da letra algo daquela estrutura musical. "Tô" pode ser vista, assim, como uma exposição brechtiana do método empregado em Estudando o samba.

$\mathrm{Na}$ sequência da canção, uma vez passado o choque de normalidade e a verbalização da proposta, Tom Zé passa a explorar, agora sim, paradoxos ao longo da terceira estrofe, como quem busca mostrar que o sentido só pode ser produzido por sua própria subversão e que o ilógico é o que há de mais lógico. Não se trata, é bom lembrar, de uma recusa pura e simples ao sentido ou de um apreço pelo ilógico. Assim como em Brecht, a inversão do sentido quer revelar que o sentido é produzido dentro de uma estrutura social que está invertida e que é ilógica. Voltaremos esse ponto mais adiante.

Após essa estrofe, o refrão retorna e é repetido diversas vezes até o fim da faixa, de uma maneira que vale ressaltar. Enquanto um coro canta a melodia da canção tal qual havia sido apresentada na primeira execução do refrão, Tom Zé se desprende desse coro e passa a desarticular a melodia, explorando intensamente os limites entre o canto e a fala, com variações bruscas de intensidade e passagens também bruscas entre todos os registros da voz, chegando mesmo ao ponto de gritar as palavras. Temos aqui o aparecimento radical do último dos principais elementos do projeto estético de Tom Zé em Estudando o samba: a sua maneira própria de cantar, aqui levada às últimas consequências. Tal elemento surge como a desestabilização da normalidade musical que imperava em "Tô", completando o movimento da canção, que vai da normalidade inesperada, passa pela explicação da proposta e acaba com o retorno à anormalidade, que, ao fim desse movimento, tem seu estatuto alterado pelo choque com a normalidade. "Tô" também marca o fim da introdução do "estudo" de Tom Zé, dessa primeira parte explicitamente programática do disco, na qual sua estética é apresentada.

"Ui! (você inventa)"

Logo mais contaremos

A história de uma viagem empreendida

Por um explorador e dois explorados.

Vocês olhem bem para o comportamento deles:

Notem que, apesar de familiar, ele é estranho

Inexplicável, apesar de comum

Revista Crioula - $\mathbf{n}^{\circ} \mathbf{2 6}$ - Relações entre literatura e música na produção de língua portuguesa

$2^{\circ}$ Semestre 2020 
Composta em parceria com Odair Cabeça de Poeta, "Ui! (você inventa)" é a sexta faixa do disco, última do lado A. A letra da canção apresenta a recorrência de uma estrutura simples que, como veremos, se reflete na estrutura do arranjo. Trata-se da oposição entre um "você" e um "eu", que se encontram em uma relação de dominação, na qual o primeiro domina o segundo, de modo que as ações de "eu" são determinadas pelas ações de "você". Quanto à forma, temos uma parte A cantada duas vezes, uma por Tom Zé e outra por um coro, uma parte B cantada uma vez por Tom Zé e a repetição da parte A, novamente realizada duas vezes, com Tom Zé cantando a primeira e o coro a segunda. A letra da parte A diz:

\author{
Você inventa: 'Grite!' \\ Eu invento: 'Ai!' \\ Você inventa: 'Chore!' \\ Eu invento: 'Ui!' \\ Você inventa o luxo \\ Eu invento o lixo \\ Você inventa o amor \\ Eu invento a solidão
}

Segundo Luiz Tatit (1986), tanto no canto como na fala, observa-se a presença de alguém dizendo alguma coisa de uma certa maneira. No primeiro, a cumplicidade daquele que diz com aquilo que se diz se dá pela melodia enquanto na segunda ela se dá pela entoação, de modo que a melodia do canto seria, em certa medida, uma extensão estetizada da entoação da fala cotidiana, na qual está implicada a relação entre um locutor (aquele que diz) e um ouvinte (aquele para quem se diz). Nesse sentido, um dos elementos relacionados à eficácia de uma canção seria sua capacidade de criar condições que simulem uma situação de fala cotidiana e proporcionem o estabelecimento da comunicação desejada com o ouvinte. Esse impulso de simular a comunicação do cotidiano, presente em maior ou menor grau em qualquer canção, Tatit chama de figurativização. Uma das maneiras pelas quais a figurativização se manifesta na letra se dá quando o locutor da canção instaura nela mesma um simulacro de sua própria relação com o ouvinte, fazendo com que haja também na letra explicitamente alguém que fala (e que, nessa relação simulada, Tatit chama de interlocutor) e alguém para quem se 
fala (o interlocutário). Como se pode ver no trecho transcrito acima, trata-se, aparentemente, de um procedimento ostensivamente utilizado na letra de "Ui! (você inventa)". No que diz respeito à melodia dessa parte A, ela parece combinar elementos de figurativização, como os grandes saltos intervalares destinados às falas presentes na letra: as interjeições "ai" e "ui" e os imperativos "grite" e "chore", e elementos de tematização, como a reiteração da melodia com que se canta "você inventa" e "eu invento" nos quatro primeiros versos.

No arranjo, observa-se intensa tematização melódica em toda a parte A. Desde o início, o arranjo tem como marca principal a oposição entre a viola e o violão, que corresponde diretamente à oposição presente na letra. Enquanto a viola realiza durante todo o trecho arpejos descendentes de três notas, atacando sempre a segunda, terceira e quarta semicolcheias do segundo tempo de cada compasso, variando de acordo com o acorde, mas sempre seguindo o padrão 5-3-1, o violão realiza arpejos ascendentes, também de três notas, também na segunda, terceira e quarta semicolcheias, mas do primeiro tempo dos compassos, de maneira a quase sempre espelhar os arpejos da viola.

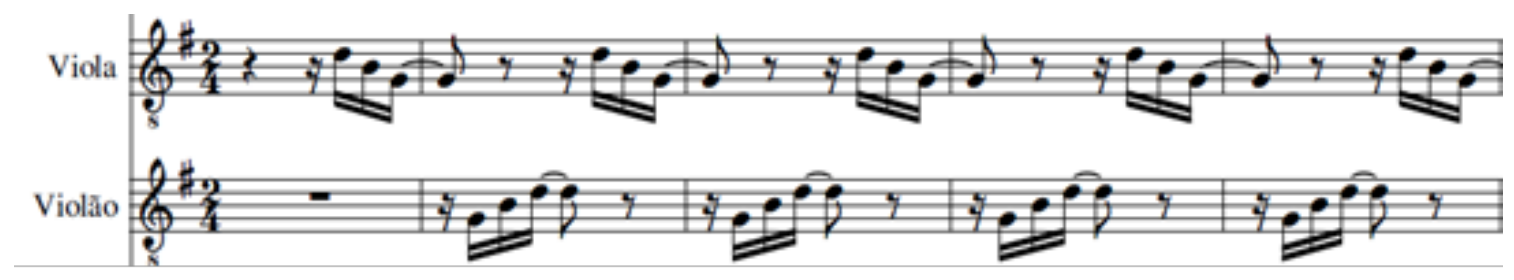

Ex. 02: arpejos da viola e do violão.

Nas duas vezes em que a parte A é cantada por Tom Zé, o arranjo tem esses dois instrumentos acrescidos apenas do baixo elétrico, que ataca regularmente os primeiros tempos dos compassos e da percussão (provavelmente um caxixi), que marca as semicolcheias. É interessante notar que essa intensa tematização presente no arranjo não se destina de forma alguma a demarcar o gênero, uma vez que não há nada na estrutura rítmica dos arpejos que remeta necessariamente ao samba, o baixo reforça os primeiros tempos e não os segundos, como seria típico do gênero e a percussão é bastante vazia, com apenas um caxixi. Apenas com a entrada do cavaquinho junto com o coro na repetição da parte A, passamos a ter um elemento que caracterize diretamente o samba. Segundo Tatit (1996), a tematização melódica é propícia para a identificação entre um tema musical que se repete e uma determinada ideia que também se repete na letra. Diante disso, nos parece que todo o arranjo desta primeira parte da música tem a função de tematizar e, portanto, reforçar a relação de dominação entre "eu" e "você" que está no centro da canção. Voltaremos a esse ponto.

Entrando na letra, vemos que essa relação é apresentada nos quatro primeiros versos em uma espécie de diálogo, com duas ordens de "você": "grite" e "chore", às quais "eu" responde com as 
interjeições "ai" e "ui". Desde esse início, coloca-se em questão o ponto de vista a partir do qual a letra se estrutura. Como já vimos acima, a relação entre um "eu” e um "você" na canção tende a se apresentar como um simulacro da relação entre o locutor da canção, que entra em síncrese com "eu" e o ouvinte, simulado por "você". No entanto, o que temos nesses quatro primeiros versos não é exatamente um diálogo entre dois personagens, mas o locutor da canção simulando um diálogo e assumindo as duas posições da relação, a fim de apresentá-la. Esse ponto de vista fica mais claro no restante da letra, que não terá mais diálogos, com a relação sendo descrita de maneira mais clara pelo “eu” da canção. Nos próximos quatro versos, entra em cena o aspecto econômico desta dominação (luxo/lixo), que chega até a dimensão afetiva (amor/solidão). Toda a parte A parece deixar claro que a relação entre "você" e "eu" é, ao mesmo tempo, de oposição e implicação. Assim como nos quatro primeiros versos as interjeições de "eu" são decorrências diretas das ordens de "você", o lixo é uma decorrência direta do luxo e a solidão uma decorrência do amor. A relação entre os arpejos da viola e do violão reforça isso na medida em que a reiteração de ambos transforma-os em pergunta e resposta, como se um pedisse o outro. Mas, assim como na letra, não se trata de uma via de mão dupla, há um sentido determinado na relação. Se observarmos que os arpejos do violão se situam no primeiro tempo e são ascendentes, poderíamos pensar que eles são a "pergunta" que pediria como "resposta" os arpejos descendentes da viola no segundo tempo. No entanto, o fato de o arpejo da viola sempre antecipar as mudanças dos acordes faz com que ele assuma a posição de independência, identificando-se com o "você" como polo dominante, de modo que os arpejos do violão decorrem dele, identificando-se com o "eu" como polo dominado.

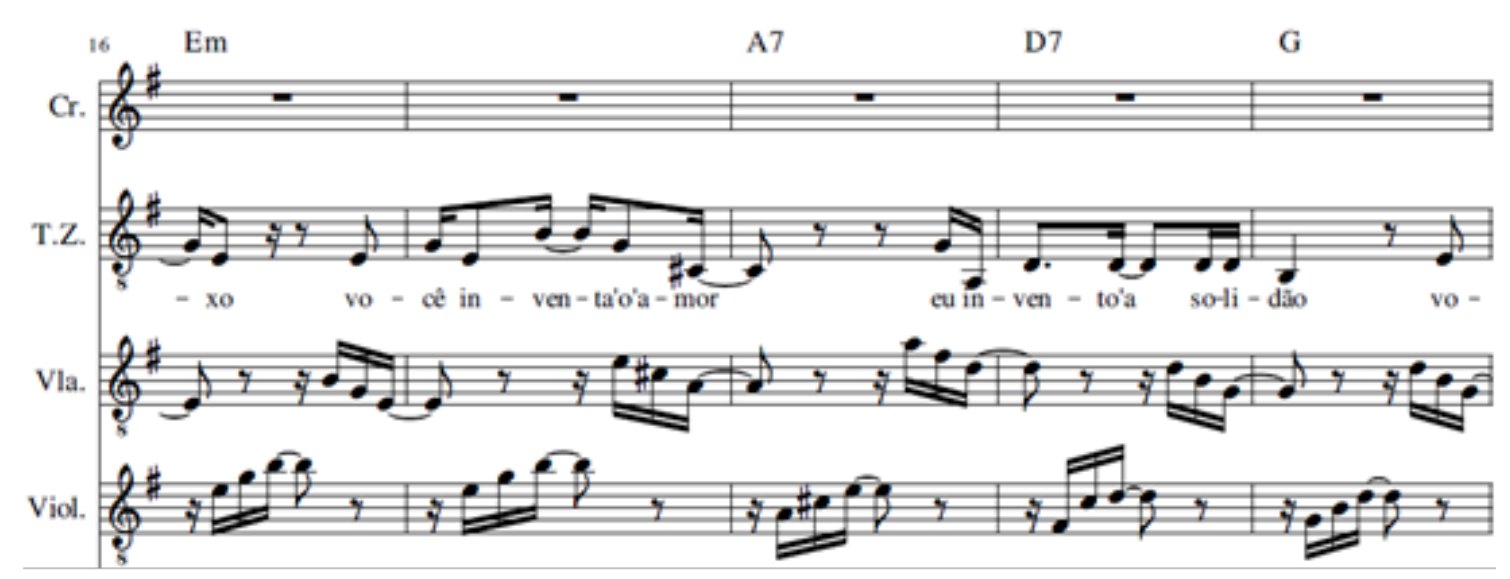

Ex. 03: Transcrição parcial da melodia e dos arpejos, com a viola antecipando as mudanças de acorde.

Nesse quadro, faz sentido que o arpejo da viola seja descendente e, portanto, o mais conclusivo, pois não se trata de uma relação de pergunta resposta, mas de "manda quem pode, obedece quem tem juízo". É exatamente isso o que nos dizem os dois primeiros versos da letra da parte $\mathrm{B}$, transcrita a 
seguir.

\author{
Você inventa a lei \\ E eu invento a obediência \\ Você inventa Deus \\ E eu invento a fé \\ Você inventa o trabalho \\ E eu invento as mãos \\ Você inventa o peso \\ E eu invento as costas \\ Você inventa a outra vida \\ Eu invento a resignação \\ Você inventa o pecado \\ E eu fico aqui no inferno \\ Meu Deus \\ No inferno \\ Valha-me Deus
}

Algo que ainda não foi dito já chamava a atenção na parte A e chama ainda mais aqui: a utilização generalizada do verbo "inventar". Tal utilização nos direciona para a desnaturalização dessa relação de dominação. Assim, todos os elementos envolvidos na dominação (lei, Deus, trabalho, pecado, luxo, amor etc.) aparecem como invenções construídas para perpetuar esta condição. Talvez, se poderia pensar numa espécie de dominação humana universal e a-histórica, pela repetição sempre idêntica da forma verbal, que faz com que seu tempo fique um tanto indeterminado, pela generalidade dos elementos envolvidos e ausência de referências históricas mais específicas. Trata-se, na verdade, de uma estrutura que é fruto de um trabalho de montagem e que pede decifração, tanto em cada um de seus elementos, como nas relações entre eles. Assim, não parece forçado afirmar que a religiosidade em questão seja da tradição judaico-cristã (um Deus único, a relação pecado/inferno), inclusive com o "valha-me Deus" no último verso nos aproximando do catolicismo popular no Brasil. Se olharmos ainda para o elemento "trabalho", pode-se dizer que o trabalho em si faz parte da condição humana universal. No entanto, justamente por essa universalidade, não se pode dizer que o trabalho nesse sentido universal tenha sido propriamente "inventado" por alguém ou um grupo de pessoas, de 
modo que esse trabalho inventado remete a uma certa configuração social do trabalho, que envolve, obviamente, dominação. Estamos diante de um sistema de dominação que se dá através de uma certa organização social do trabalho, associada a um sistema legal (lei/obediência), uma religião, que nos parece justo afirmar que seja cristã, com seu código moral e que gera uma grande desigualdade econômica (luxo/lixo). Há um outro elemento que, em uma primeira leitura, pode parecer um pouco deslocado, mas que, caso não estejamos forçando a análise, nos aproxima de especificar qual sistema de dominação opera nesta canção. Falamos da relação amor/solidão. Tal relação parece envolver também um tipo bastante específico de amor: trata-se do amor romântico, que como se sabe, envolve uma concepção moderna de indivíduo, sendo característico das sociedades burguesas. Estamos diante então de uma dominação que parece capitalista, mas isso ainda é pouco. O único momento em que o "eu" da canção se situa um pouco mais ocorre bem no fim, quando o verbo muda e aparece o dêitico "aqui", em "e eu fico aqui no inferno". Vemos então que esse "eu" se encontra em uma situação de bastante desespero, na qual the resta apenas a expressão de súplica "valha-me Deus", que, se não for necessariamente brasileira, parece ser bastante típica da língua portuguesa e fortemente associada ao catolicismo.

Se formos para a parte musical, observaremos que essa parte B é bastante diferente da anterior. $\mathrm{O}$ arranjo perde os arpejos que tematizavam a relação de dominação na parte $\mathrm{A}$, o cavaquinho e o baixo. O violão passa a tocar uma batida de bossa nova e a percussão passa a ter um surdo marcando os tempos, com acento no segundo. Em termos de gênero (ou estilo), passamos a ter uma junção curiosa entre um violão à maneira de João Gilberto e uma percussão à maneira da batucada de samba, que não é usualmente utilizada na bossa nova. Esse movimento do arranjo de começar tematizando a relação apresentada na letra sem nenhuma referência direta ao samba, trazer elementos de samba na repetição da parte A com o cavaquinho e o coro, para na parte B caracterizar uma bossa nova com um elemento da batucada de samba parece partir de uma relação de dominação em termos mais gerais, para ir progressivamente situando-a no Brasil, contendo nessa parte B um elemento moderno (violão da bossa nova) e um elemento tradicional (batucada de samba).

Voltando para a relação de dominação e tentando identificar o que está por trás dela, é interessante notar a maneira como Tom Zé costuma introduzir essa canção em suas apresentações ao vivo. Há dois registros dela em álbuns ao vivo: um emNo jardim da política (1998) e outro no CD O pirulito da ciência (2009). Em ambos, ela é apresentada como um telegrama feito por Tom Zé e seu parceiro Odair Cabeça de Poeta endereçado ao presidente dos EUA a fim de propor um acordo de paz que evitasse um possível conflito militar motivado pela concorrência comercial entre o forró brasileiro e o rock americano ${ }^{5}$. Ainda que essa introdução não exista no disco que estamos analisando, ela oferece uma chave valiosa para pensar sobre o ponto de vista a partir do qual a canção é construída: tratar-se-

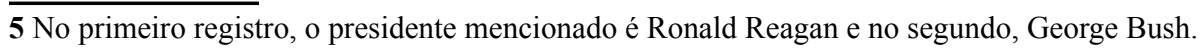

Revista Crioula - n 26 - Relações entre literatura e música na produção de língua portuguesa

$2^{\circ}$ Semestre 2020 
ia, assim, não de uma denúncia ou de uma descrição da relação de dominação, mas de uma proposta, uma tentativa de acordo do "eu" para com o "você", muito mais poderoso, o que justifica a utilização de "você" e não "ele". Ora, como pode o "eu" estar propondo a sua própria exploração? É a partir dessa contradição que o ponto de vista da canção e a profundidade de seu esquema aparentemente simples se revelam. Podemos dizer que "Ui" apresenta de maneira interessante aquilo que Maria Rita Kehl (2018) chama de "ponto de vista do cabo do chicote". A expressão é retirada do romance Quincas Borba, de Machado de Assis, no qual, a certa altura, o narrador diz que "tão certo é que a paisagem depende do ponto de vista, e que a melhor maneira de apreciar o chicote é ter-lhe o cabo na mão". Nesse sentido, uma das principais características do narrador machadiano seria o fato de ele assumir acintosamente o ponto de vista de quem detém o cabo do chicote, de modo a causar certo escândalo no leitor'. "Ui”, por outro lado, é, como vimos, cantada do ponto de vista daquele que está sendo açoitado, o qual parece consentir com quem detém o cabo do chicote. Cabe então questionar que tipo de formação social abarca uma relação de dominação de um grau tal que a parte dominada aceita a própria exploração, a fim de evitar um conflito maior e propõe a perpetuação dessa condição na forma de um acordo.

Voltando para a letra da parte A, observa-se logo no começo, além da demarcação imediata das posições desiguais, de "eu" e "você", um certo sadismo da parte deste último, que faz questão de ver o sofrimento de "eu", ordenando que ele "grite" e "chore", ordens que são prontamente atendidas. Parece se tratar de algo próximo daquilo que Roberto Schwarz (2006) chama de "exercício do abuso pelo abuso" (p. 22) e que se constitui, segundo o autor na matéria explorada por Machado de Assis em outro romance, Memórias póstumas de Brás Cubas. Tal matéria diz respeito ao Brasil escravocrata da segunda metade do século XIX, mas não parece ser uma relação de escravidão que opera em "Ui". Em linhas muito gerais, o que caracteriza essa matéria histórica é a incongruência entre as ideias e valores iluministas, que inspiraram em alguma medida a independência e a formação do Brasil como Estado-nação, e a base social brasileira, sustentada pelo trabalho escravo (incompatível com o trabalho livre e que o desmente) e por relações de favor (incompatíveis com os princípios de igualdade e impessoalidade da lei e que os desmentem). Nesse sentido, uma das grandes façanhas de Machado de Assis foi formalizar a desfaçatez de uma classe dominante (os que detêm o cabo do chicote) que ostentava os valores ilustrados europeus enquanto mantinha e se favorecia das relações de escravidão e clientelismo ${ }^{7}$. Esse tipo de relação social em vez de entrar em conflito com aquelas ideias acomodou-se a elas e permaneceu ao longo do tempo, assumindo novas feições conforme os processos de modernização política e econômica exigiram. Voltando aos quatro primeiros versos de "Ui", essa relação de dominação do "abuso pelo abuso" se parece com as relações de dominação

6 Para uma análise formal detalhada a respeito do narrador machadiano, ver Roberto Schwarz (2006).

7 Para maiores considerações sobre a importação de ideias burguesas em uma estrutura social escravocrata e todas as decorrências disso, ver, de Roberto Schwarz, Ao vencedor as batatas (2000), em especial o primeiro capítulo, “As ideias fora do lugar”, e também o segundo ensaio de Que horas são? (1989), intitulado"Nacional por subtração". 
regidas pelo favor que caracterizam a matéria histórica brasileira, nas quais o lado dominado está à mercê dos arbítrios e caprichos do mais poderoso. Não custa lembrar ainda que esse é o primeiro elemento apresentado da relação, de modo a ressoar sobre os seguintes. Assim, antes e acima da lei, do amor e do trabalho (todos em suas formas burguesas) estão os caprichos daquele que domina.

Enquanto a natureza da relação entre "eu" e você" começa a ficar mais clara, ainda não se pode dizer o mesmo sobre o ponto de vista em que se situa esse "eu". Com efeito, ele se encontra no polo dominado de uma relação estruturalmente desigual e se dirige àquele que o domina propondo uma acomodação na forma de um acordo clamorosamente injusto para que seja evitado um conflito. No entanto, não se pode dizer que se trata de um acordo propriamente dito, uma vez que a ideia de um acordo entre dois sujeitos pressupõe um mínimo de igualdade, nem que seja meramente formal, entre as partes. O fato de tal igualdade não existir aqui nem mesmo em aparência torna o "acordo" risível e um disparate. São vários os elementos formais da canção que jogam luz sobre o aspecto risível e, no limite, falso do acordo. Além de todos os elementos absurdos que vão sendo empilhados como se não houvesse nada de estranho, há a reiteração do verbo "inventa", que, como vimos, tende a desnaturalizar cada um dos elementos. Mais do que isso, quem está desnaturalizando a dominação é o lado dominado que, ao mesmo tempo em que demonstra notável clareza e consciência acerca dos aspectos envolvidos na estrutura desigual da relação, propõe a sua perpetuação. É interessante, a esse respeito, a maneira como aparece o aspecto religioso da dominação: o polo dominado enxerga com clareza que Deus, pecado, inferno e "a outra vida" são invenções que produzem nele fé e resignação, contribuindo para a produção de um quadro que o mantém no "inferno". Ao perceber-se no inferno, a reação do "eu" é uma súplica resignada ao Deus que, versos antes, ele mesmo afirmava ser uma invenção, para então recomeçar a parte A. Parece seguro dizer que o efeito humorístico causado por esse acúmulo de absurdos é intencional, e sua ironia é reforçada por um elemento fundamental da estética de Tom Zé, de que trataremos agora.

Até aqui, deixamos de lado um aspecto importantíssimo para abordarmos a complicada questão do ponto de vista nesta canção: a maneira como Tom Zé canta toda a melodia. Começamos a análise falando da relação entre canto e fala porque toda a interpretação de Tom Zé explora intensamente os limites entre uma coisa e outra. Isso chega a se refletir nas próprias melodias cantadas por ele. Dissemos que a melodia da parte A apresenta traços de tematização e figurativização, mas se compararmos a mesma parte A cantada por Tom Zé e pelo coro, fica claro que o iraraense canta com uma rítmica menos regular e com saltos intervalares maiores, mais frequentes e mais inesperados, aproximandose da indeterminação da fala cotidiana e submetendo a melodia às exigências entoativas da letra. A mesma característica se observa em toda a parte B, mas a exploração de Tom Zé vai muito além disso. Chama a atenção o tipo de colocação de voz com a qual ele canta as notas, buscando uma voz cotidiana, próxima da fala ou, como se diz, com a voz "fora do lugar". Dentro dessa colocação de voz 
próxima da fala, Tom Zé explora uma série de variações. Em alguns momentos, coloca bastante peito na voz; em outros, quebra para o falsete; em alguns, procura trazer marcas da garganta para o som; já em outros, busca uma voz anasalada. É possível identificar ainda a busca por aquilo que Regina Machado(2012) chama de "voz suja":

Uma voz "suja" é aquela na qual se ouve, além das alturas expressas pela linha
melódica, um pequeno chiado, uma projeção de ar ou mesmo um ligeiro tensionamento
que resulta numa quase rouquidão. Por oposição, uma voz "limpa" é aquela na qual se
ouve apenas a pureza das alturas da melodia expressas pelo timbre. (p. 140)

Além disso, a maneira de atingir e deixar as notas é interessante. Tom Zé não economiza nos portamentos ${ }^{8}$, glissandos ${ }^{9}$ e qualquer procedimento que desestabilize as notas. Ora as notas são atacadas por baixo, para depois serem atingidas de fato, ora são atacadas em cheio e desestabilizadas depois do ataque. No entanto, Tom Zé sempre passa pela nota em algum momento, ou seja, o canto nunca deixa de ter alturas definidas e, via de regra, passando sempre por notas das tríades dos acordes sobre os quais se encontra a melodia. Ou seja, essa desestabilização das notas não pode ser confundida com dissonância. Trata-se de uma canção com pouquíssimas dissonâncias na harmonia, com diversos acordes em tríades simples e tétrades apenas para aqueles que exercem função de dominante. A melodia, por sua vez, respeita rigorosamente as tríades e tétrades, procurando não se chocar com a harmonia. A dimensão rítmica do canto de Tom Zé também se aproxima da indeterminação da fala. De modo geral, é bastante difícil, às vezes mesmo impossível, determinar exatamente onde caem os ataques de Tom Zé dentro do compasso. Uma das razões para isso parece ser o fato de que, ainda que a base rítmica do arranjo se mantenha estável ao longo da canção, Tom Zé parece cantar a melodia em uma espécie sutil de rubato, acelerando algumas palavras e esticando outras.

De onde viria, no entanto, esse canto aproximado da fala? Uma referência com a qual o disco Estudando o samba e todo o trabalho de Tom Zé dialogam frequentemente é, como sabemos, João Gilberto, cujo canto é famoso por aproximar-se da fala. Todavia, em João a relação entre canto e fala é de absoluta harmonia e marcada pela estabilidade, como se não houvesse conflito algum entre uma coisa e outra. Como afirma Mammí sobre esse canto, “[o] horizonte ideal do processo é um ponto em que seja suficiente falar com perfeição para que a linha melódica brote espontaneamente da palavra, uma vez encontrada a inflexão e a cor exata de cada sílaba” (1992, p. 68). Se o movimento de João Gilberto é o de buscar uma fala tão perfeita que se transforme em canto, o de Tom Zé parece ser o oposto: buscar um canto tão imperfeito que se transforme em fala. Nos termos de Regina Machado

$\overline{8}$ "Deslizamento, intencional ou não, na mudança entre uma nota e a que se lhe segue" (DOURADO, 2004, p. 260).

9 "Consiste em saltar de uma nota a outra com pouca ou nenhuma distinção de sons intermediários, em uma espécie de longo portamento" (DOURADO, 2004, p. 148). 
(2012), João Gilberto seria um exemplo lapidar de "voz limpa", em tudo oposta à "voz suja" de Tom Zé. Luiz Tatit (2004)já havia observado isso: "Pode-se dizer que, ao contrário do procedimento habitual dos cancionistas de estetizar o cotidiano, Tom Zé cotidianizava a estética: inseria as imperfeições, as insuficiências, os defeitos." (2004, p. 237-38). Trata-se então de uma estética que, sem ser abandonada, incorpora a si elementos que lhe são estranhos, relativizando-se. Em vez do canto como extensão estetizada da fala, a fala como extensão desestetizada do canto, movimento este que pressupõe o anterior.

Esse canto "defeituoso" se constituinuma característica importante da estética própria de Tom Zé, e é utilizado não apenas em "Ui! (você inventa)", mas também em "Dói”, "Tô", outras faixas de Estudando o samba em menor intensidade e praticamente em toda a obra do iraraense. Cabe ainda uma tentativa de especificar que sentidos isso pode assumir. No caso de "Ui! (você inventa)", parece haver uma outra referência para a aproximação entre canto e fala. O tom fortemente declamatório com que Tom Zé canta especialmente a parte B, aliado a certa liberdade rítmica de seu rubato traz uma associação com o canto recitativo, muito usado na música erudita, especialmente em óperas e cantatas. Se não estivermos enganados, isso nos leva não para a dimensão da música erudita, mas para um canto com um forte componente teatral ${ }^{10}$. Desse modo, os procedimentos enumerados acima, por meio dos quais Tom Zé traz elementos da fala para o canto, parecem se destinar a teatralizar a relação de dominação presente na letra. O cantor assume o papel do "eu" da canção como se interpretasse um personagem, a partir de cujo ponto de vista a relação é apresentada, com alta dose de uma ironia imprimida na voz de Tom Zé por sua maneira de cantar. Vimos acima que, quando fala sobre o ato de cantar em seu relato autobiográfico, o iraraense rejeita o canto emotivo, que gera um "transe dramático" e propõe um novo "acordo tácito" entre cantor e público com o objetivo de substituir a "empatia gerada pela emoção" e romper com o "elo forjado pela dramatização expressionista". Diante disso, a construção dessa maneira defeituosa de cantar constitui-se num dos principais recursos através dos quais Tom Zé busca evitar a identificação emotiva no canto, substituindo-a por uma desidentificação, na qual o próprio ato de cantar encontra-se relativizado. Se o canto "expressionista" era visto por Tom Zé como uma encenação, seu canto defeituoso também o é, mas trata-se de uma encenação que procura revelar, ao invés de esconder, seu aspecto artificial.

Temos então uma relação de dominação violenta colocada na forma de um acordo impossível (mas possível) no qual a parte dominada tem a palavra e narra os termos do acordo, demonstrando a um só tempo enorme consciência de sua condição e um conformismo maior ainda, revelando a ironia

10 Cabe lembrar aqui da convivência e proximidade de Tom Zé com Augusto Boal. No show No jardim da política(1984), posteriormente lançado em CD em 1998, Tom Zé faz a seguinte menção a Boal ao apresentar a canção "Minha carta", a qual antecede "Ui! (você inventa)": "Quando eu cheguei aqui em São Paulo, eu convivi com uma pessoa maravilhosa, o Augusto Boal, no Teatro de Arena. Ele gostava de dizer à gente assim: 'Olha, quando vocês olham até pra Lua, vocês estão fazendo política!' Isso porque ele já sentia que no ambiente que ele tava trabalhando - era eu, Gil, Caetano, Gal - ele sentia que era uma turma mais ou menos de 'Divino, maravilhoso' e tal, então ele ficava dando umas liçõezinhas". Cabe lembrar também que Arena canta Bahia não foi o único trabalho de Tom Zé como ator. Ele trabalhou, por exemplo, durante seus anos de ostracismo, mais precisamente em 1975, em uma montagem da peça Rocky Horror Show, com direção de Rubens Correia, no Teatro da Praia, no Rio de Janeiro. 
do conjunto, a qual é reforçada por uma maneira de cantar que relativiza o próprio ato de cantar e busca evidenciar que o "eu" da canção é um personagem e que tudo se passa como em uma cena. Ao mesmo tempo em que Tom Zé mostra estar assumindo um papel em uma cena, no interior da própria canção, como vimos, o "eu" assume o papel do "você", com o qual também não se confunde. Tomados em seu conjunto, esses procedimentos têm o efeito de apresentar brechtianamente um aspecto corriqueiro da realidade social - uma relação entre explorador e explorado -, de maneira a mostrar que ele é estranho apesar de familiar, comum apesar de impossível e, acima de tudo, uma construção histórica. A montagem dos elementos que compõem a dominação contribui para o quadro. Apesar de muito simples à primeira vista, ela busca dar luz à relação inseparável que leis, religião, trabalho e até o amor possuem com a exploração econômica ${ }^{11}$, além de apontar para a maneira como tal dominação se dá no Brasil, com a prática do "abuso pelo abuso".

Vimos acima que a canção "Tô" joga com a aproximação de ideias antagônicas de maneira a produzir às vezes paradoxos, às vezes contrassensos, às vezes obviedades, mas sempre um efeito de estranhamento, que desfamiliariza o familiar e familiariza o desfamiliar, realizando verbalmente o que as faixas anteriores realizavam musicalmente. Nesse sentido, "Ui (você inventa)" completa o movimento iniciado em "Tô". Todos esses recursos de distanciamento na obra de Brecht se destinam a cumprir um imperativo de revelar algo sobre as reais dinâmicas que envolvem as relações capitalistas, desnaturalizando aquilo que nelas tende a se apresentar como universal ou natural e mostrando seu caráter histórico, situado e construído. Segundo Anatol Rosenfeld,

[o] tornar estranho, o anular da familiaridade da nossa situação habitual, a ponto de ela ficar estranha a nós mesmos, torna esta situação mais conhecida e mais familiar. O distanciamento passa a ser então negação da negação; leva através do choque do não conhecer ao choque do conhecer. Trata-se de um acúmulo de incompreensibilidade até que surja a compreensão. Tornar estranho é, portanto, ao mesmo tempo, tornar conhecido (2008, p. 152).

A diferença entre "Tô" e "Ui (você inventa)" está naquilo a que se refere o distanciamento. Na primeira, Tom Zé está tratando de seus próprios procedimentos musicais e apresentando-os ao ouvinte. A intenção parece ser a de relativizar samba, bossa nova, tropicalismo e MPB, todos consolidados como ramos importantes e legitimados da canção popular brasileira, e nos quais Tom Zé não se insere, para mostrar a linguagem proposta pelo compositor, que se constrói aproveitando os elementos desses estilos a partir da elaboração de um ponto de vista de outsider. Em "Ui (você inventa)", por outro 11 Roberto Schwarz lembra, ao analisar Brecht, que "o escândalo inicial da crítica materialista (...) esteve em afirmar que o capital, que é uma relação de classe, é o segredo e a chave da sociedade burguesa, inclusive de seu direito, do estado, da moralidade e da cultura. Longe de serem incondicionadas e de promoverem a universalidade humana que proclamavam, estas esferas formariam sistema com a exploração econômica, a qual, uma vez reconhecida pelos explorados como um fato de classe, sem caução divina ou natural, estaria com os dias contados" (1999, p. 144). 
lado, talvez se possa dizer que a aproximação com Brecht é ainda mais oportuna, pois não se trata de falar sobre música. O que se apresenta com distanciamento e "acúmulo de incompreensibilidade" é uma relação de exploração, o que coloca como alvo do distanciamento justamente a "nossa situação habitual". Ao mesmo tempo, os dois procedimentos se aproximam. Em "Tô" (e nas três faixas anteriores), ao falar sobre música, colocando-se fora de estilos consagrados no mercado e propondo algo diferente, Tom Zé também desvela algo sobre a "nossa situação habitual", talvez até de maneira mais forte do que em "Ui (você inventa)", a saber, a falsidade da ideologia largamente difundida de que "há espaço para todos no mercado". Em "Ui (você inventa)", por sua vez, embora não se esteja falando de música, um recurso indispensável para compor o quadro da relação absurda e apresentá-la com ironia é de ordem musical: o canto defeituoso, que, como vimos, aparece pela primeira vez no disco exatamente em "Tô".

\section{Referências}

BOMFIM, Leonardo Corrêa. Os tons de Zé: transformações paradigmáticas na obra de Tom Zé (1967-1976). Dissertação de Mestrado em Música. São Paulo: Universidade Estadual Paulista “Júlio de Mesquita Filho”, 2014.

BRECHT, Bertolt. Teatro completo v. 4. 2. ed. Rio de Janeiro: Paz e Terra, 1990.

DIAS, Marcia Tosta. Os donos da voz: indústria fonográfica brasileira e mundialização da cultura $2^{\mathrm{a}}$ ed. São Paulo: FAPESP/Boitempo Editorial, 2008.

DIAS, Marcia Tosta. "Quando o todo era mais do que a soma das partes: álbuns, singles e os rumos da música gravada”. Revista Observatório Itaú Cultural. $n^{\circ} 13$ (set. 2012). São Paulo: Itaú Cultural, 2012, p. 63-74.

DOURADO, Henrique Autran. Dicionário de termos e expressões da música. São Paulo: Editora 34, 2004.

DUNN, Christopher. "Fazendo cócegas nas tradições: o samba disjuntivo de Tom Zé". Revista do Instituto de Estudos Brasileiros, $n$. 70, p. 149-165, ago. 2018.

FREIRE, Guilherme Araújo. Vanguarda, experimentalismo e mercado na trajetória artística de Tom Zé. Dissertação de Mestrado em Música. Campinas: Universidade Estadual de Campinas, 2015.

GONÇALVES, Patrícia Anette Schroeder. Três ensaios sobre a Tropicália de Tom Zé: da "Era dos Festivais" à "Era dos Editais”. Dissertação de Mestrado em Estudos Brasileiros. São Paulo: IEB-USP, 2018.

KEHL, Maria Rita. Bovarismo brasileiro. São Paulo: Boitempo, 2018.

MACHADO, Regina. Da intenção ao gesto interpretativo: análise semiótica do canto popular brasileiro. Tese de doutorado em linguística. São Paulo: FFLCH-USP, 2012.

MAMMÌ, Lorenzo. “João Gilberto e o projeto utópico da bossa nova”. Novos Estudos, $n^{\circ}$ 34. São Paulo, Cebrap, nov. 1992. pp. 63-70. 
MAMMÌ, Lorenzo. “A era do disco”. Revista Piauí, no 89. Rio de Janeiro: Editora Alvarenga, 2014. pp. 36-41.

NAPOLITANO, Marcos. "A música popular brasileira (MPB) dos anos 70: resistência política e consumo cultural". Actas del V Congresso Latinoamericano IASPM, 2002.

NAPOLITANO, Marcos. “MPB: a trilha sonora da abertura política (1975/1982)”. Estudos avançados, nº 69, vol. 24. São Paulo, USP/ IEA, 2010. pp. 389-402.

ROSENFELD, Anatol. O teatro épico. $6^{\text {a }}$ edição. São Paulo: Perspectiva, 2008.

SCHWARZ, Roberto. Que horas são? São Paulo: Companhia das Letras, 1989.

SCHWARZ, Roberto. Sequências brasileiras. São Paulo: Companhia das Letras, 1999.

SCHWARZ, Roberto. Ao vencedor as batatas. 5a edição. São Paulo: Editora 34, 2000.

SCHWARZ, Roberto. Um mestre na periferia do capitalismo. 4ª edição, 2 ${ }^{\mathrm{a}}$ reimpressão. São Paulo: Editora 34, 2006.

SOARES, Leilor Miranda. "Batiza esse neném”: mercado, MPB, samba e processo social em Estudando o samba, de Tom Zé. Dissertação de Mestrado em Estudos Brasileiros. São Paulo: IEB-USP, 2019.

TATIT, Luiz. A canção: eficácia e encanto. São Paulo: Atual, 1986.

TATIT, Luiz. O cancionista: composição de canções no Brasil. São Paulo: Edusp, 1996.

TATIT, Luiz. O século da canção. São Paulo: Ateliê Editorial, 2004. 